\title{
Correlation between allochthonous subsidy input and isotopic variability in the giant kelp Macrocystis pyrifera in central California, USA
}

\author{
Melissa M. Foley ${ }^{1,3, *}$, Paul L. Koch ${ }^{2}$ \\ ${ }^{1}$ University of California Santa Cruz, Ecology and Evolutionary Biology, Long Marine Lab, 100 Shaffer Rd., Santa Cruz, \\ California 95060, USA \\ ${ }^{2}$ University of California Santa Cruz, Earth and Planetary Sciences, 1156 High St., Santa Cruz, California 95064, USA \\ ${ }^{3}$ Present address: Stanford University, Center for Ocean Solutions, 99 Pacific St. Suite 155a, Monterey, California 93940, USA
}

\begin{abstract}
Isotope values of primary producers can vary greatly across space and time due to changes in physiological status and the source of subsidies used in photosynthesis. Forests of the giant kelp Macrocystis occur in temperate oceans around the world and are positioned at the land-sea interface where they may receive subsidies from terrestrial and open ocean sources. In this study, we investigated the spatial and temporal variability in $\delta^{13} \mathrm{C}$ and $\delta^{15} \mathrm{~N}$ values of $M$. pyrifera over $3 \mathrm{yr}$ in Big Sur, California, USA. During each of those $3 \mathrm{yr}, \delta^{13} \mathrm{C}$ and $\delta^{15} \mathrm{~N}$ values of $M$. pyrifera varied significantly by season, with low values occurring in the spring, and high values in the fall. To examine the possible mechanisms driving this seasonal variability, we used step-wise multiple regression analyses to test whether the variability in kelp isotope values was correlated with the variability in nitrate concentration or the delivery of subsidies via upwelling circulation and river discharge. We found that temporal variation in kelp isotope values was most strongly related to the strength of upwelling and the concentration of nitrate in surface waters. The results of this study increase our understanding of the mechanisms that drive the temporal and seasonal isotopic variability in marine primary producers. This study also highlights the importance of measuring isotope variability at the base of the food chain in order to create more robust trophic predictions.
\end{abstract}

KEY WORDS: Macrocystis $\cdot$ Kelp $\cdot$ Stable isotopes $\cdot$ Allochthonous subsidies $\cdot$ Upwelling Resale or republication not permitted without written consent of the publisher

\section{INTRODUCTION}

Like many temperate coastlines around the world, the nearshore marine communities of central California (USA) are dominated by forests of the giant kelp Macrocystis pyrifera. These kelp forests are highly productive and provide structure, habitat, and protection for many ecologically and economically important species (Foster \& Vanblaricom 2001, Graham et al. 2007). M. pyrifera is considered a foundation species, and its persistence and longevity are highly dependent on macro- (e.g. nitrate, phosphate; Dayton et al. 1999) and micronutrients (e.g. iron, zinc; Manley 1981) for growth and reproductive success, as well as on a source of dis- solved inorganic carbon (DIC), such as aqueous $\mathrm{CO}_{2}$ $\left(\mathrm{CO}_{2(\mathrm{aq})}\right)$ or bicarbonate $\left(\mathrm{HCO}_{3}{ }^{-}\right)$for photosynthesis (Raven 1970, Raven et al. 2008). In nearshore marine systems, the source of essential nutrients and DIC may have multiple origins, including atmospheric, terrestrial, and/or oceanic (Fogel et al. 1992, Matsunaga et al. 1999, Bowen \& Valiela 2008). We focused our attention in this study on the delivery of allochthonous DIC and nitrate (hereafter referred to collectively as subsidies) delivered to nearshore $M$. pyrifera communities from terrestrial and oceanic sources.

Along the coast of Big Sur in central California, inputs from upwelling and river outflow come together in a nearshore habitat dominated by Macrocystis 
pyrifera (hereafter referred to as Macrocystis). A seasonal upwelling center develops near Point Sur, at the northern end of the Big Sur coastline, delivering nutrient-rich water to surface waters from approximately April through July. This influx of upwelled nutrients drives primary production (Kudela et al. 2006), delivery of larvae (Broitman et al. 2008), and ultimately contributes to the structure and functioning of entire nearshore marine food webs (Croll et al. 2005, Barth et al. 2007). River outflow in Big Sur is consistent with other short, steep watersheds where highly seasonal rainfall causes rapid flushing events that can deliver substantial loads of nutrients, particulate matter, and sediments to nearshore waters (Lyons et al. 2002, Warrick \& Fong 2004, Warrick et al. 2005).

Stable isotope analyses can be used to determine the source and extent of uptake of subsidies (Fry 2006). As discussed in greater detail in the 'Discussion', there are distinct differences in the carbon and nitrogen isotope signatures of inputs delivered via upwelling circulation, advection of oceanic surface waters, and terrestrial sources (Fogel et al. 1992, Rau et al. 1998, Kjonaas \& Wright 2007) that allow us to investigate how Macrocystis uses the multi-source subsidies throughout the year. Because DIC and nitrate delivery to the surface of Macrocystis blades is dependent on basin-wide circulation and turbulent water mixing (Hurd 2000, Buschmann et al. 2004), the rate of delivery and concentration of inputs can vary substantially over the course of a year and potentially cause significant variation in the isotope values of Macrocystis.

Our study was designed to determine how the delivery of subsidies from highly episodic, short-lived flushing events from rivers, along with more sustained seasonal delivery of subsidies from upwelling, combine to influence the patterns of subsidy use in Macrocystis. Based on the timing of subsidy delivery and the distinct isotope signature of the different subsidy sources, we investigated 3 hypotheses: (1) $\delta^{13} \mathrm{C}$ and $\delta^{15} \mathrm{~N}$ values in kelp tissue will be lowest during the winter and early spring (January to April), when high-flow river events and the delivery of terrestrial-derived subsidies with low isotopic values are greatest. We expected this effect to be more pronounced at sites closest to river inputs and for blades collected from $5 \mathrm{~m}$ depth (versus $15 \mathrm{~m}$ ), because low-density freshwater plumes tend to form a layer on the surface ocean; (2) $\delta^{13} \mathrm{C}$ and $\delta^{15} \mathrm{~N}$ values will increase during the spring and early summer (April to July), when the delivery of upwelling subsidies with intermediate isotope values is strongest along the Big Sur coast. We did not expect the effects of upwelling to vary significantly with river proximity or depth; (3) $\delta^{13} \mathrm{C}$ and $\delta^{15} \mathrm{~N}$ values will be highest in the late summer and fall (August to December), when terrestrial inputs are minimal, upwelling circulation is diminished, and onshore movement of surface waters is highest, potentially decreasing the rate of replenishment of DIC and nutrients. We expected this effect to be consistent across depth and site. Understanding the source of subsidies that plants are using and the mechanisms that drive delivery has become increasingly important as the dynamics of nutrient delivery, supply, and cycling change worldwide as a result of habitat modification (Marshall 2000, Schindler \& Scheuerell 2002) and changes in ocean circulation and temperature in response to climate change (Diffenbaugh et al. 2004).

\section{MATERIALS AND METHODS}

Site information. We conducted this study from February 2005 to September 2007 and focused on the 2 dominant rivers along the Big Sur coast: the Big Sur River (BSR) and Big Creek (BCK). The BSR in northern Big Sur drains approximately $74 \mathrm{~km}^{2}$ and loses $2000 \mathrm{~m}$ of elevation over $15 \mathrm{~km}$. BCK, located within the University of California's Landels-Hill Big Creek Reserve, is $35 \mathrm{~km}$ south of the BSR, drains approximately $40 \mathrm{~km}^{2}$, and loses $1800 \mathrm{~m}$ of elevation over $10 \mathrm{~km}$. Throughout most of the year these rivers have low base flows $\left(\sim 0.6 \mathrm{~m}^{-3} \mathrm{~s}^{-1}\right)$, but rates increase markedly during rain events $\left(>30 \mathrm{~m}^{-3} \mathrm{~s}^{-1}\right)$. Within each river study area, we monitored 3 nearshore kelp forest sites: 2 sites adjacent to the river input (river north, $\mathrm{RN}_{\text {; }}$ river south, $\mathrm{RS}$; collectively referred to as river sites) and 1 site 4 to $6 \mathrm{~km}$ north of the river input equidistant between the river of interest and the next river to the north (nonriver, NR; Fig. 1).

Input delivery variables. To determine how the delivery of allochthonous subsidies affected the isotope values of Macrocystis tissue, environmental data were either obtained from public databases or measured (Fig. 2). Upwelling data were obtained from NOAA's Pacific Fisheries Environmental Laboratory (www.pfeg.noaa.gov/) for $36^{\circ} \mathrm{N}, 122^{\circ} \mathrm{W}$ (study sites located at $36^{\circ} \mathrm{N}, 121^{\circ} \mathrm{W}$ ); average daily river discharge rates and height data for the BSR were obtained from the US Geological Survey (http://waterdata.usgs.gov/ nwis/uv?11143000), and river height for BCK was obtained from the NOAA Southwest Pacific Fisheries Science Center in Santa Cruz, California. Because the dynamics of river height were similar for both rivers throughout our study period, we used the discharge rates from the BSR for all of our analyses.

We measured the concentration of inorganic nitrate plus nitrite (hereafter referred to as nitrate) at upstream and nearshore sites at least monthly from February 2005 to September 2007 and at the peak of the river hydrograph during all significant ( $>2 \mathrm{~cm}$ in $24 \mathrm{~h}$ ) rain events. When ocean conditions allowed, samples 
a

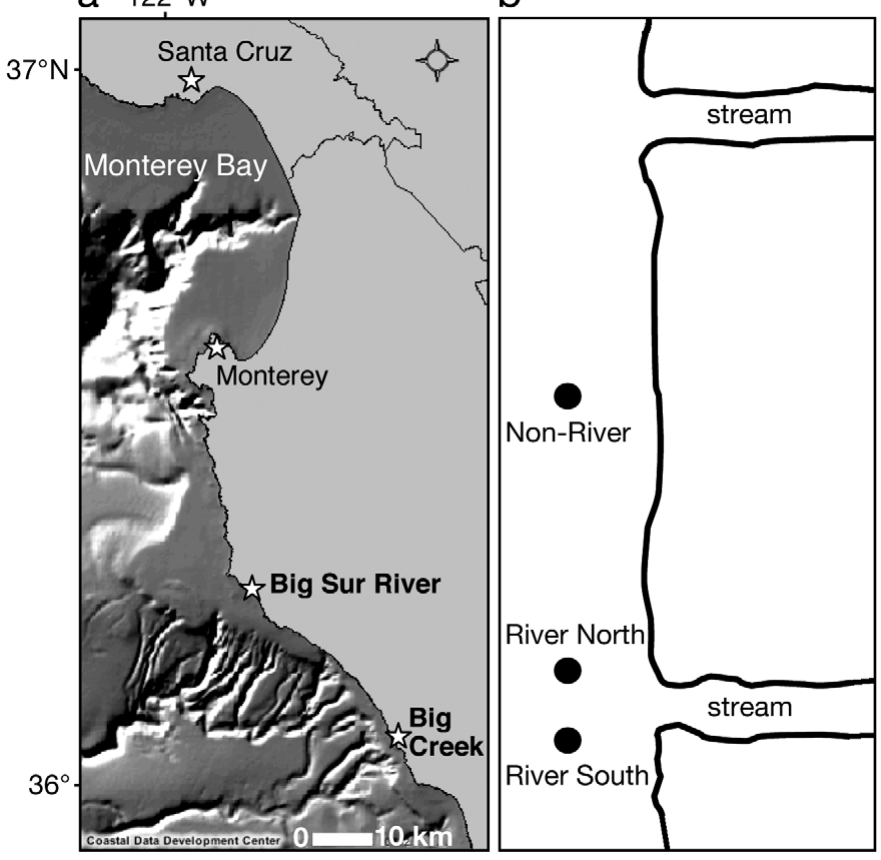

Fig. 1. (a) Central California, showing the location of the Big Sur River (BSR) and Big Creek (BCK) watersheds. (b) Locations of nearshore sites in relation to the river outflow for both river areas (not to scale). Actual nearshore site locations: BSR-NR $\left(36^{\circ} 18.122^{\circ} \mathrm{N}, 121^{\circ} 53.884^{\circ} \mathrm{W}\right)$, BSR-R $\left(36^{\circ} 16.575^{\circ} \mathrm{N}\right.$, $\left.121^{\circ} 51.945^{\circ} \mathrm{W}\right), \quad$ BCK-NR $\quad\left(36^{\circ} 16.130^{\circ} \mathrm{N}, \quad 121^{\circ} 53.912^{\circ} \mathrm{W}\right)$, BCK-R $\left(36^{\circ} 16.426^{\circ} \mathrm{N}, 121^{\circ} 51.885^{\circ} \mathrm{W}\right)$; NR: non-river; R: river

were collected from NR, RN, and RS nearshore sites. When we could not access our nearshore sites by boat, samples were collected from intertidal areas directly onshore of RN and NR nearshore sites. Therefore, for each sampling event, we collected samples from upstream and intertidal or nearshore sites at the BSR and BCK areas. Samples were collected from $1 \mathrm{~m}$ below the surface in acid-cleaned HDPE bottles, filtered through a pre-ashed $25 \mathrm{~mm} \mathrm{GF/F}$ with a pore size of $0.7 \mu \mathrm{m}$, and the filtrate was collected in acid-cleaned $20 \mathrm{ml}$ plastic scintillation vials. Samples were transported on ice and stored in a $-20^{\circ} \mathrm{C}$ freezer until they were analyzed on a Latchet Quikchem 8000 Flow Injection Analyzer at the University of California Santa Cruz's Marine Analytical Lab using standard colorimetric methods (Parsons et al. 1984).

Isotope values. To determine whether subsidies from terrestrial and upwelling sources were being used by Macrocystis, we collected kelp tissue samples monthly at all nearshore sites from spring to early winter as ocean conditions allowed. We collected a total of 6 blades from multiple plants at 5 and $15 \mathrm{~m}$ below the surface; blade condition was standardized to the best of our ability. Blades were transported on ice and stored in a $-20^{\circ} \mathrm{C}$ freezer until further processing. We cut a $12 \mathrm{~cm}^{2}$ piece from the blade approximately $10 \mathrm{~cm}$
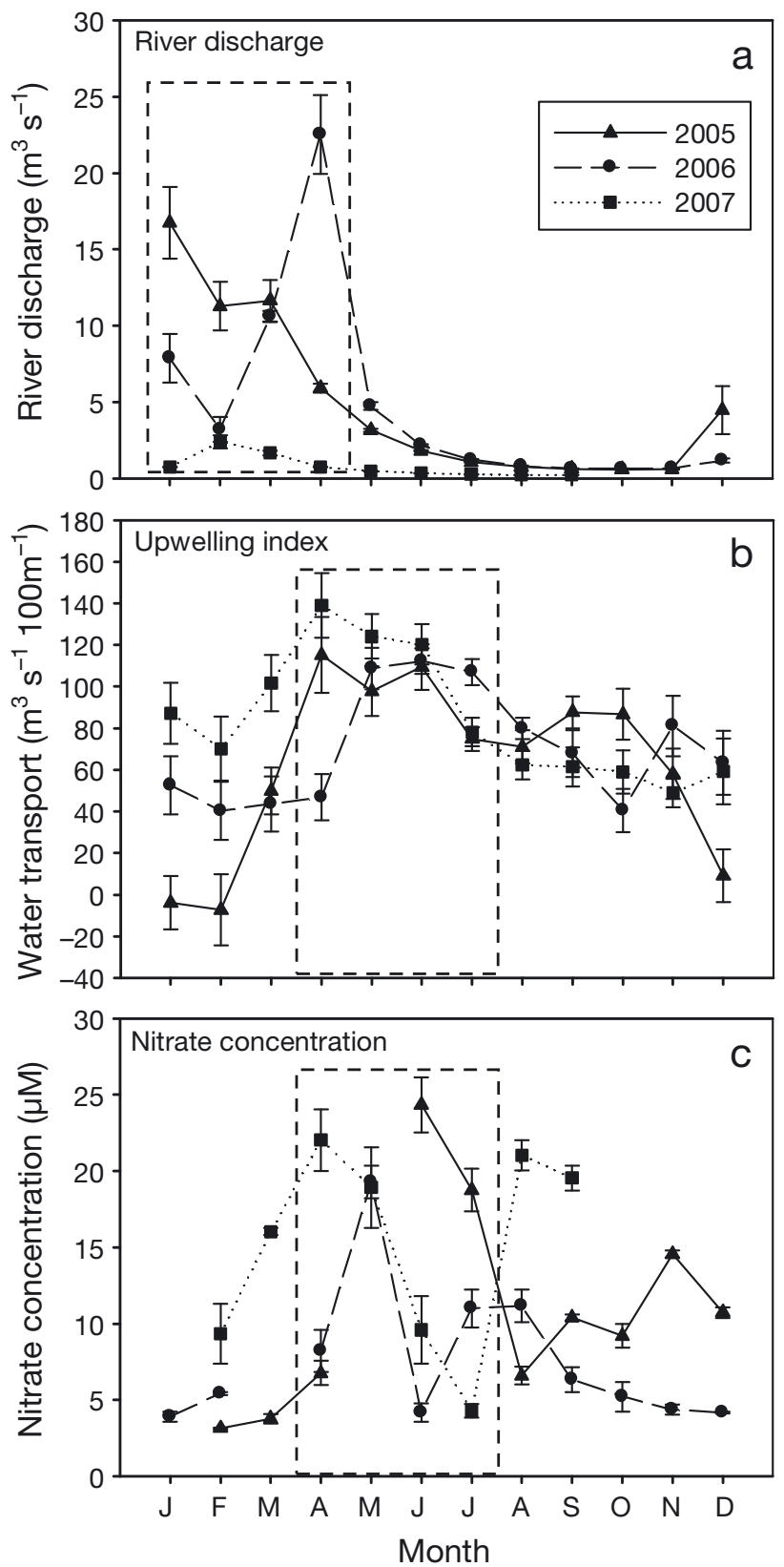

Fig. 2. Mean ( $\pm 1 \mathrm{SE})$ monthly values for (a) river discharge, (b) upwelling strength, and (c) nitrate concentration for 2005, 2006, and 2007. Areas within dashed boxes indicate the season with significantly higher values

above the bladder-blade junction. Each piece was scraped clean of epiphytes, dipped in a $10 \% \mathrm{HCl}$ solution, rinsed with Milli-Q water, dried in a $60^{\circ} \mathrm{C}$ oven for $48 \mathrm{~h}$, and ground into a fine powder with a mortar and pestle. Two milligrams of tissue were weighed into tin capsules on a microbalance and analyzed for $\delta^{13} \mathrm{C}$ and $\delta^{15} \mathrm{~N}$ values. Samples were analyzed at the University of California Santa Cruz on a Thermo Finnegan Delta- 
Plus XP mass spectrometer (Thermo Electron Corporation) interfaced with a Carlo Erba elemental analyzer (EA1108). Isotope values are reported in standard delta notation, $\delta^{\mathrm{H} X}(\%)=\left[\left(\mathrm{R}_{\text {sample }} / \mathrm{R}_{\text {std }}\right)-1\right] \times 1000$, where $\mathrm{X}$ is the element, $\mathrm{H}$ is the mass of the heavier isotope, and $\mathrm{R}$ is the heavy-to-light isotope ratio of the sample or standard. The standard for carbon is Vienna Peedee Belemnite Limestone; the standard for nitrogen is atmospheric nitrogen. Repeated measures of calibrated internal PUGel $(\mathrm{n}=126)$ and acetanilide (n $=42$ ) standards were used to quantify analytical precision (SD in PUGel was $\leq 0.2 \%$ for both $\delta^{13} \mathrm{C}$ and $\delta^{15} \mathrm{~N}$; SD in acetanilide was $0.25 \%$ for $\delta^{13} \mathrm{C}$ and $0.4 \%$ for $\left.\delta^{15} \mathrm{~N}\right)$.

Statistical analyses. We used analysis of variance (ANOVA) methods to test for between-season and between-site (where available) differences for each of the input variables. Differences in Macrocystis isotope values were tested using a random effects linear mixed model including proximity to river input, depth $(5$ versus $15 \mathrm{~m}$ ), season (upwelling: March through July; nonupwelling: August through February), and all possible interactions as fixed factors, and river area as a random factor. We were unable to collect kelp samples during January and February in all years, so we had an equal number of months in the upwelling versus nonupwelling analyses. For these analyses, an alpha level of 0.05 was considered significant. Because interpretation of the main effects of the random effects linear mixed model was confounded by significant interaction terms, we also ran a variance components model to determine how much of the explained variance could be attributed to each term (Quinn \& Keough 2002).

Inputs from upwelling and river sources have highly variable temporal patterns (Fig. 2), and the isotopic end members of the subsidies are not well constrained for our system, making the use of isotope mixing models difficult. We therefore used correlation analyses to determine whether the temporal variations in $\delta^{13} \mathrm{C}$ and $\delta^{15} \mathrm{~N}$ values of kelp tissue were related to the temporal patterns in input variables and nitrate concentration. We performed multiple regression analyses with stepwise estimation to determine the best-fit model for the data. Input delivery factors included average monthly values for river discharge and upwelling strength and snap-shot monthly values for nitrate concentration averaged across the 3 years of the study. The multipleregression model tested for significant relationships between the variability in kelp isotope values and the variability in input measurements from the same month and with a 1 mo lag. We included this lag in the model to account for times when kelp tissue turnover rate may be slower than $30 \mathrm{~d}$. This lag period was chosen based on the results from cross-correlation analyses (CCA) and the average lifespan ( 2 to $3 \mathrm{mo}$ ) and growth rate of kelp blades. There were no significant lags longer than $1 \mathrm{mo}$ in the CCA, suggesting that it is physiologically unlikely that conditions experienced longer than 1 mo before would be reflected in the basal portion of kelp blade tissue. We used the CCA to inform the multiple regression model because our data were too unevenly spaced for time series analyses. For all step-wise regression analyses, variables were considered significant and remained in the model if they had an alpha level of 0.15 or lower. A higher alpha level was used in these correlative tests, since multiple factors were likely to be contributing to the variation in isotope values of kelp blade tissue. All analyses were performed using Systat v12 (Systat Software).

\section{RESULTS}

\section{Input delivery variables}

The subsidy input variables we tested were chosen because they can affect the delivery rate, and thereby concentration, of DIC and nitrate from terrestrial and oceanic sources to nearshore waters. In this system, high river discharge events and increased upwelling circulation were temporally separated and showed marked seasonal trends (Fig. 2). Average river discharge rate from 2005 to 2007 was significantly different during wet and dry seasons $(\mathrm{df}=1,31$, ANOVA $F=$ $10.4, \mathrm{p}=0.003)$, with higher discharge between November and April (mean $\pm 1 \mathrm{SE} ; 6.4 \pm 1.6 \mathrm{~m}^{-3} \mathrm{~s}^{-1}$ ) than between May and October $\left(1.2 \pm 0.3 \mathrm{~m}^{-3} \mathrm{~s}^{-1}\right.$; Fig. 2). There was also a significant seasonal difference in upwelling strength $(\mathrm{df}=1,34$, ANOVA $F=23.3, \mathrm{p}<$ 0.001 ) and nitrate concentration ( $\mathrm{df}=1,24$, ANOVA $F$ $=4.8, \mathrm{p}=0.04)$. Unlike river discharge, higher upwelling strength and nitrate concentration occur from April to July (upwelling: $102.8 \pm 7.3 \mathrm{~m}^{-3} \mathrm{~s}^{-1}$ $100 \mathrm{~m}^{-1}$; nitrate: $15.3 \pm 2.1 \mu \mathrm{M}$ ) than from August to March (upwelling: $57.1 \pm 5.6 \mathrm{~m}^{-3} \mathrm{~s}^{-1} 100 \mathrm{~m}^{-1}$; nitrate:

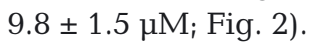

\section{$\delta^{13} \mathrm{C}$ values}

Macrocystis samples collected between July 2005 and September 2007 varied considerably in both $\delta^{13} \mathrm{C}$ and $\delta^{15} \mathrm{~N}$ values. The variability was generally seasonal, with lower values occurring during the spring and early summer and higher values during the late summer and fall. The results of the random effects linear mixed model analysis suggest that the depth $\times$ season and depth $\times$ river proximity interactions and the main effects of season and depth were the main contributors to variability in $\delta^{13} \mathrm{C}$ values (Table 1 ). The 
Table 1. Macrocystis pyrifera. Effects of river proximity, season, and depth on $\delta^{13} \mathrm{C}$ and $\delta^{15} \mathrm{~N}$ values in kelp blade tissue. Values in bold are significant at $\mathrm{p}<0.05$

\begin{tabular}{|c|c|c|c|c|c|}
\hline \multirow{2}{*}{ Random effects model } & \multirow[b]{2}{*}{ df } & \multicolumn{2}{|c|}{$-\delta^{13} \mathrm{C}-$} & \multicolumn{2}{|c|}{$\delta^{15} \mathrm{~N}$} \\
\hline & & $t$ & $\mathrm{p}$ & $t$ & $\mathrm{p}$ \\
\hline \multicolumn{6}{|l|}{ Random effects } \\
\hline \multirow[t]{2}{*}{ River area } & 442 & 0.92 & 0.36 & 0.94 & 0.35 \\
\hline & df & $F$ & $\mathrm{p}$ & $F$ & $\mathrm{p}$ \\
\hline \multicolumn{6}{|l|}{ Fixed effects } \\
\hline River proximity & 1,442 & 0.38 & 0.54 & 0.23 & 0.63 \\
\hline Season & 1,442 & 81.06 & $<0.001$ & 176.35 & $<0.001$ \\
\hline Depth & 1,442 & 13.06 & $<0.001$ & 16.68 & $<0.001$ \\
\hline Season $\times$ river proximity & 1,442 & 0.10 & 0.75 & 0.23 & 0.63 \\
\hline Depth $\times$ river proximity & 1,442 & 7.71 & 0.006 & 2.15 & 0.14 \\
\hline Depth $\times$ season & 1,442 & 16.42 & $<0.001$ & 4.68 & 0.03 \\
\hline $\begin{array}{l}\text { Depth } \times \text { season } \times \text { river } \\
\text { proximity }\end{array}$ & 1,442 & 0.62 & 0.43 & 0.57 & 0.45 \\
\hline
\end{tabular}

ation in isotope and tissue composition values. The results suggest that $\delta^{13} \mathrm{C}$ values were most tightly correlated with upwelling and nitrate concentration (Table 2). At BCK sites, there was a significant relationship between $\delta^{13} \mathrm{C}$ values and non-lagged upwelling values at both depths (Fig. 4a, Table 2). Tissue $\delta^{13} \mathrm{C}$ values from sites at BSR showed a similar pattern at $5 \mathrm{~m}$, while blades from $15 \mathrm{~m}$ were correlated with the 1 mo lagged upwelling values (Table 2). In addition, $\delta^{13} \mathrm{C}$ values from BSR sites at 5 and $15 \mathrm{~m}$ were also significantly correlated with the $1 \mathrm{mo}$ lagged nitrate concentrations depth $\times$ season interaction was driven by strong depth gradients in $\delta^{13} \mathrm{C}$ values during spring and early summer that were absent during the late summer and fall (Fig. 3). The significant interaction between depth and river proximity was driven by a stronger depth gradient in $\delta^{13} \mathrm{C}$ values at non-river sites compared to river sites. The results from the variance components model suggest that season (upwelling versus non-upwelling) explained a majority of the explained variance (65\%) in $\delta^{13} \mathrm{C}$ values, and the depth $\times$ season interaction explained an additional $28 \%$ of the explained variance.

Step-wise multiple regression analyses allowed us to examine whether the temporal variation in input delivery was associated with the temporal and spatial vari-

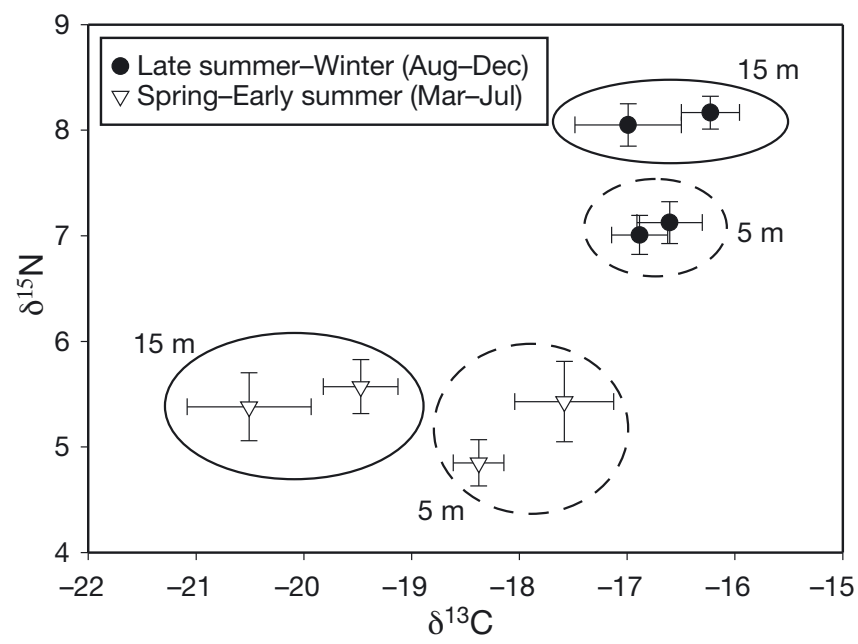

Fig. 3. Macrocystis pyrifera. Mean $( \pm 1 \mathrm{SE}) \delta^{13} \mathrm{C}$ and $\delta^{15} \mathrm{~N}$ values of kelp blade tissue at $5 \mathrm{~m}$ (dashed circles) and $15 \mathrm{~m}$ (solid circles) depth in spring to early summer $(\nabla)$ and late summer to winter
(Fig. 4c, Table 2). At all BCK and BSR sites, $\delta^{13} \mathrm{C}$ values were lower when upwelling strength and/or nitrate concentration were high.

\section{$\delta^{15} \mathrm{~N}$ values}

The results from the $\delta^{15} \mathrm{~N}$ random effects linear mixed model show a significant depth $\times$ season interaction and a significant effect of season and depth (Table 1). The depth $\times$ season interaction showed the opposite pattern of $\delta^{13} \mathrm{C}$ values; there was no difference in $\delta^{15} \mathrm{~N}$ values between depths during the spring and early summer, but there was a significant difference between depths during the late summer and fall (Fig. 3). The variance components model for $\delta^{15} \mathrm{~N}$ values showed that the main effect of season explained nearly $90 \%$ of the explained variation.

The variability in $\delta^{15} \mathrm{~N}$ values was also significantly related to the variability in upwelling strength and nitrate concentration. At BCK sites, $\delta^{15} \mathrm{~N}$ values at both 5 and $15 \mathrm{~m}$ were significantly correlated to non-lagged upwelling values (Fig. 4b); $\delta^{15} \mathrm{~N}$ values at 5 and $15 \mathrm{~m}$ at BSR sites were significantly correlated with 1 mo lagged upwelling values (Table 2). The $\delta^{15} \mathrm{~N}$ values at both depths at BSR sites were also significantly correlated with 1 mo lagged nitrate concentrations (Fig. 4d). Similar to $\delta^{13} \mathrm{C}$ values, $\delta^{15} \mathrm{~N}$ values at all sites were negatively correlated with upwelling strength and nitrate concentration.

\section{DISCUSSION}

Nearshore waters are in nearly constant flux due to current and wave forces that move nutrients, particulates, and individuals through the system. It is therefore reasonable to predict that isotope values of 
Table 2. Macrocystis pyrifera. Step-wise regression analysis for kelp isotopic values versus non-lagged and 1 mo lagged environmental variables at 2 depths (5 and 15 m). BCK: Big Creek; BSR: Big Sur. Values in bold are significant at p < 0.15. (-): variables that were not significant and were thus dropped from the step-wise regression analysis

\begin{tabular}{|c|c|c|c|c|c|c|}
\hline \multirow{2}{*}{ Multiple regression } & \multicolumn{2}{|c|}{ Discharge } & \multicolumn{2}{|c|}{ _ Upwelling } & \multirow[b]{2}{*}{$F$} & \multirow{2}{*}{ Nitrate } \\
\hline & $F$ & $\mathrm{p}$ & $F$ & $\mathrm{p}$ & & \\
\hline \multicolumn{7}{|l|}{ No lag } \\
\hline $\mathrm{BCK} \delta^{13} \mathrm{C}_{;} 5 \mathrm{~m}$ & - & - & 11.68 & 0.005 & - & - \\
\hline $\mathrm{BCK} \delta^{15} \mathrm{~N}_{i} 5 \mathrm{~m}$ & - & - & 12.30 & 0.003 & - & - \\
\hline $\mathrm{BCK} \delta^{13} \mathrm{C} ; 15 \mathrm{~m}$ & - & - & 9.86 & 0.007 & - & - \\
\hline BCK $\delta^{15} \mathrm{~N}_{i} 15 \mathrm{~m}$ & 14.24 & 0.003 & 17.84 & 0.001 & - & - \\
\hline $\mathrm{BSR} \delta^{13} \mathrm{C}_{i} 5 \mathrm{~m}$ & - & - & 7.62 & 0.02 & - & - \\
\hline $\mathrm{BSR} \delta^{13} \mathrm{C}_{i} 15 \mathrm{~m}$ & - & - & - & - & 5.28 & 0.04 \\
\hline \multicolumn{7}{|l|}{1 mo lag } \\
\hline BSR $\delta^{13} C_{;} 5 \mathrm{~m}$ & - & - & - & - & 8.16 & 0.02 \\
\hline $\mathrm{BSR} \delta^{15} \mathrm{~N} ; 5 \mathrm{~m}$ & - & - & 12.20 & 0.005 & 4.70 & 0.05 \\
\hline $\mathrm{BSR} \delta^{13} \mathrm{C}_{i} 15 \mathrm{~m}$ & - & - & 8.96 & 0.01 & 3.93 & 0.07 \\
\hline $\mathrm{BSR} \delta^{15} \mathrm{~N} ; 15 \mathrm{~m}$ & - & - & 11.08 & 0.007 & 8.01 & 0.02 \\
\hline
\end{tabular}

aquatic macrophytes will be particularly dynamic due to constantly changing delivery and concentration of DIC and nutrients in the nearshore ocean that can affect macrophyte physiology.
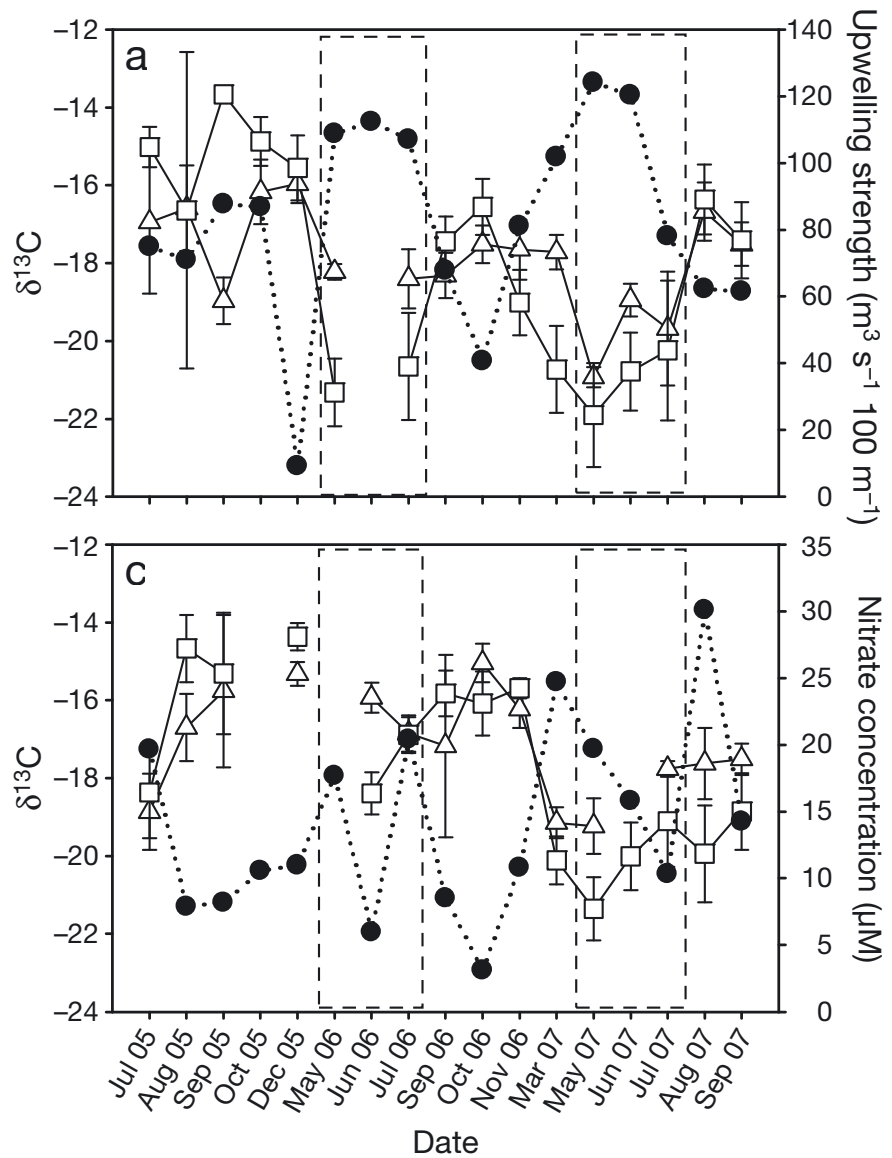

The $\delta^{13} \mathrm{C}$ value of marine algae is most strongly impacted by factors relating to photosynthetic processes, including the concentration of $\mathrm{CO}_{2(\mathrm{aq})}$, the dominant form of DIC used (i.e. $\mathrm{CO}_{2 \text { (aq) }}$ or $\mathrm{HCO}_{3}{ }^{-}$), the $\delta^{13} \mathrm{C}$ value

Fig. 4. Macrocystis pyrifera. Negative relationship between $\delta^{13} \mathrm{C}$ and $\delta^{15} \mathrm{~N}$ and $(\mathrm{a}, \mathrm{b})$ non-lagged upwelling strength at Big Creek sites, and (c,d) 1 mo lagged nitrate concentration at Big Sur sites for kelp blades collected at 5 and $15 \mathrm{~m}$ depth; area within the dashed lines indicates the typical upwelling season in Big Sur 
of inorganic carbon sources, and photosynthetic rate and physiology (Cifuentes et al. 1988, Bernasconi et al. 1997, Rau et al. 1997), i.e. processes that affect isotopic fractionation. There are 4 carbon pools that may support nearshore photosynthesis off the Big Sur coast. Terrestrial DIC, produced by oxidation of $\mathrm{C}_{3}$ vegetation on land, has the lowest $\delta^{13} \mathrm{C}$ values, and is typically between -15 and $-5 \%$ o (Kaldy et al. 2005, Waldron et al. 2007), with the lowest values occurring during highflow events (Doctor et al. 2008). The $\mathrm{CO}_{2(\mathrm{aq})}$ and $\mathrm{HCO}_{3}{ }^{-}$ that are brought to the surface by upwelling have the next lowest values $\left(\delta^{13} \mathrm{C}_{\text {DIC }}\right.$ approx. $-0.3 \%$ ). This pool is relatively enriched in ${ }^{12} \mathrm{C}$ by remineralization of marine organic matter delivered to the ocean floor from the surface ocean. 'Local' DIC formed by invasion of atmospheric $\mathrm{CO}_{2}$ into the surface ocean will have variable $\delta^{13} \mathrm{C}$ values, dependent on local water temperature, but will be more ${ }^{13} \mathrm{C}$-enriched than upwelled water. The most ${ }^{13} \mathrm{C}$-enriched carbon will occur in surface water that advects into nearshore waters $(0.8$ to $1.5 \%$ ) that has experienced significant prior photosynthesis followed by export production of ${ }^{12} \mathrm{C}$-enriched organic matter to the ocean floor (Ortiz et al. 2000).

Primary producer $\delta^{15} \mathrm{~N}$ values depend largely on the $\delta^{15} \mathrm{~N}$ of the sources of nitrogen (i.e. upwelling, terrestrial input, atmospheric deposition), nitrogen concentration, and the dominant form of nitrogen used (i.e. $\mathrm{NO}_{3}{ }^{-}$or $\mathrm{NH}_{4}{ }^{+}$; Handley \& Scrimgeour 1997, Ostrom et al. 1997). $\mathrm{NO}_{3}{ }^{-}$is the dominant form of DIN in nearshore waters (Zehr \& Ward 2002), so we focused our attention on the $\delta^{15} \mathrm{~N}$ value of $\mathrm{NO}_{3}{ }^{-}$from different sources. The $\delta^{15} \mathrm{~N}$ of terrestrially-derived DIN can range widely depending on land use within a watershed. In forested, mainly intact watersheds, $\delta^{15} \mathrm{~N}$ is largely driven by microbial activity in the soil, and ranges from -2 to $+4 \%$ (Spoelstra et al. 2001, Mitchell et al. 2006). Upwelled nitrate in the Monterey Bay region has an intermediate $\delta^{15} \mathrm{~N}$ value and is typically around 7 to $8 \%$ o (Rau et al. 1998). Surface water nitrate that can be advected onshore when upwelling circulation is relaxed can have $\delta^{15} \mathrm{~N}$ values as high as $14 \%$ due to high rates of photosynthesis (Wankel et al. 2007). Atmospheric deposition, which we did not measure in this study, is not expected to be substantial since there are no dense population centers or major sources of industrial inputs in the region.

\section{Terrestrial input delivery}

In our first hypothesis, we predicted that if terrestrial DIC and nitrate subsidies were important contributors to kelp growth, then kelp isotope values would be lowest from January to March, particularly at river sites, due to the episodic input of ${ }^{13} \mathrm{C}$-depleted DIC and
${ }^{15} \mathrm{~N}$-depleted nitrate from terrestrial sources that are delivered during high-flow river discharge events. Although isotope values were lowest in the spring, we did not find a significant correlation between river discharge rates and $\delta^{13} \mathrm{C}$ or $\delta^{15} \mathrm{~N}$ values, nor was there a significant difference between isotopic values at nonriver versus river sites. Our sample size for winter was severely limited, however, due to stormy, rough ocean conditions that were unfavorable for sampling. Discharge events along the Big Sur coast deliver a large amount of particulate and dissolved organic materials to the nearshore environment (M. Foley unpubl. data), but these subsidies are delivered over a short period of time (1 to $3 \mathrm{~d}$ ) and are likely to be moved quickly offshore by turbulent mixing from large waves. It is possible that we did not detect any correlations between $\delta^{13} \mathrm{C}$ or $\delta^{15} \mathrm{~N}$ values and river discharge because the short-lived delivery of isotopically-distinct, terrestrially-derived DIC and nitrate sources were swamped by the more stable supply of marine-derived subsidies. In any case, our results support the conclusion that terrestrial subsidies contribute little carbon and nitrogen to support kelp growth. We did not address hypotheses related to other terrestrial inputs (i.e. micronutrients such as Fe, sediments that contribute to turbidity).

\section{Upwelling input delivery}

In our second hypothesis, we predicted that isotope values in Macrocystis from April to July would be slightly higher than values from January to March due to an increase in upwelled sources of DIC and nitrate with intermediate isotope values. Upwelling strength is greatest from April to July along the Big Sur coast (Fig. 2) and was significantly correlated with the low $\delta^{13} \mathrm{C}$ and $\delta^{15} \mathrm{~N}$ values we found in kelp tissue (Fig. 3), contrary to our prediction.

The delivery of carbon with intermediate $\delta^{13} \mathrm{C}$ values to the nearshore ocean during the upwelling season coincides with increased nutrient concentration and light availability. The combination of these 3 abiotic factors in the early spring creates a highly favorable environment for Macrocystis, and growth rates are typically highest during this period (Zimmerman \& Kremer 1986, Reed et al. 2008), especially at 3 to $4 \mathrm{~m}$ below the surface where light levels are higher than at the bottom (Wheeler 1977). Plants photosynthesizing at high rates can deplete the $\mathrm{CO}_{2(\mathrm{aq})}$ pool at the blade surface and even begin to draw down total DIC in the water column, resulting in higher plant $\delta^{13} \mathrm{C}$ values (Farquhar et al. 1989). Thus, despite the fact that upwelled DIC is more ${ }^{13} \mathrm{C}$-enriched than terrestrial DIC and that kelp grows rapidly on the Big Sur coast during the upwelling season, we did not see an 
increase in $\delta^{13} \mathrm{C}$ values during this season. This suggests that the carbon pool was being replenished at a fast enough rate to make up for photosynthetic removal, perhaps by upwelling or by increased alongshore currents during the spring and early summer (Woodson et al. 2007). However, there was a significant difference between $\delta^{13} \mathrm{C}$ values in blades collected at 5 and $15 \mathrm{~m}$ depth during the upwelling period (Fig. 3), suggesting that blades at $5 \mathrm{~m}$ may have been drawing down $\mathrm{CO}_{2(\text { aq) }}$ at a faster rate, resulting in higher $\delta^{13} \mathrm{C}$ values.

In addition to replenishing the DIC pool, upwelling circulation injects cold, nutrient-rich water to surface waters, resulting in a significant positive correlation between nearshore nitrate concentration and upwelling intensity (Barth et al. 2007). Due to upwelling circulation, increased nitrate concentration can also be accompanied by increased along-shore currents during the spring and early summer (Woodson et al. 2007), which are likely to increase water flow through the kelp bed and aid in the delivery of fresh pools of nutrients to the surface of kelp blades (Hurd 2000). Plants typically have lower $\delta^{15} \mathrm{~N}$ values if the nitrogen pool is in excess in the system, due to the discrimination against the heavy isotope during enzymatic update and fixation (Ostrom et al. 1997). If the source pool is completely consumed, however, discrimination decreases and the $\delta^{15} \mathrm{~N}$ value of the plant converges on the $\delta^{15} \mathrm{~N}$ value of the nitrogen source, a common scenario in most regions of the ocean (Altabet \& Francois 1994). Rau et al. (1998) found that the particulate nitrogen pool in Monterey Bay had an average $\delta^{15} \mathrm{~N}$ value of $7.6 \%$ when the nitrate pool was completely drawn down, and $\delta^{15} \mathrm{~N}$ values of $\sim 8 \%$ or greater are expected in upwelled water along the northeastern California margin (Altabet et al. 1999). The $\delta^{15} \mathrm{~N}$ of our kelp samples was approximately $5 \%$ during the upwelling season, suggesting that the nitrate pool was not being locally depleted. Despite the fact that the $\delta^{15} \mathrm{~N}$ value of upwelled nitrate is heavier than terrestrial nitrate, the high concentration of nitrate delivered via upwelling, along with increased water flow through the kelp bed during the spring and early summer, may drive lower $\delta^{15} \mathrm{~N}$ values in kelp blades throughout the water column.

\section{Minimal input delivery}

Our third hypothesis was that in the late summer and early fall, because of the use of relatively ${ }^{13} \mathrm{C}$ - and ${ }^{15} \mathrm{~N}$ enriched subsidies and the reduced input of all subsidies (minimal terrestrial input or upwelling, low nitrate concentration), we would observe the highest kelp isotope values. Our data showed a consistent pattern of high $\delta^{13} \mathrm{C}$ and $\delta^{15} \mathrm{~N}$ values across all years during this time period, suggesting that the DIC pool at the blade surface becomes more ${ }^{13} \mathrm{C}$-enriched as the rate of carbon uptake exceeds the rate of replenishment. This decrease in replenishment of $\mathrm{CO}_{2(\mathrm{aq})}$ supply to the blade surface is likely to occur in the late summer and early fall due to decreased water exchange within the center of a kelp bed as a result of reduced upwelling strength, low wave heights, and a dense kelp canopy (Gaylord et al. 2007, Hepburn et al. 2007). Diffusion limitation of $\mathrm{CO}_{2}$ at the blade surface may increase the dependence of algal species on bicarbonate $\left(\mathrm{HCO}_{3}{ }^{-}\right)$, which requires additional enzymes and energy and results in higher $\delta^{13} \mathrm{C}$ values in algal tissue (Raven 1970, Raven et al. 2002).

We also saw a decrease in nitrate concentration as upwelling intensity decreased. This change in nutrient delivery was accompanied by a shift of $\delta^{15} \mathrm{~N}$ values from $\sim 5 \%$ in the spring to $\sim 8 \%$ in the fall. The latter values are close to $\delta^{15} \mathrm{~N}$ values for both particulate nitrogen (7.6\%; Rau et al. 1998) and particles collected in sediment traps $(7.8 \%$ ) in Monterey Bay (Altabet et al. 1999), suggesting a complete utilization of the nitrate pool, resulting in higher $\delta^{15} \mathrm{~N}$ values. We also found a significant difference between depths in the late summer and fall, with higher and more variable $\delta^{15} \mathrm{~N}$ values at 15 than at $5 \mathrm{~m}$ (Fig. 3). Although there was a significant difference between the $\delta^{15} \mathrm{~N}$ values at these 2 depths, the $\delta^{15} \mathrm{~N}$ values for both depths overlap published values for subsurface nitrate ( 7 to $8 \%$; Altabet et al. 1999). However, the slight difference in $\delta^{15} \mathrm{~N}$ values between depths may also indicate that blades at $5 \mathrm{~m}$ use another nitrogen source, such as ammonium, which is excreted by epiphytic hydroids and bryozoans on the kelp blade surface (Hepburn \& Hurd 2005).

\section{SUMMARY}

Stable isotope analyses can be used effectively to investigate the spatial and temporal patterns of subsidy use in primary producers. Along the Big Sur coast from 2005 to 2007, $\delta^{13} \mathrm{C}$ values of Macrocystis blade tissue ranged from -25 to $-13 \%$ and $\delta^{15} \mathrm{~N}$ values ranged from 2 to $10 \%$. We found that the strong seasonal trend in these values was associated with the shift from high upwelling intensity and nitrate concentration in the spring and early summer to low upwelling intensity and nitrate concentration in the late summer and fall. The $\delta^{13} \mathrm{C}$ and $\delta^{15} \mathrm{~N}$ values from Page et al. (2008), the only published study of Macrocystis values from the US west coast (Santa Barbara Channel, California), have a much smaller range in isotope values $\left(\delta^{13} \mathrm{C}\right.$ : -13.8 to $-12.2 \%$; $\delta^{15} \mathrm{~N}$ : 8.5 to $9.7 \%$ ) and are consistently higher than the values we found in Big Sur. The large difference in isotope values between these 2 
regions within the California Current system highlights the importance of understanding how local-scale oceanographic conditions, nutrient sources, and algal physiology can affect stable isotope values of primary producers.

Our findings make important contributions to understanding the mechanisms driving isotopic variability in primary producers. However, the large amount of temporal variation in the isotope values of Macrocystis in our study underscores the variability of primary producers over short temporal and spatial scales, making it difficult to generalize results or observations across the geographic range of this ecologically important species. Our results also have implications for understanding the relationship between Macrocystis and higher trophic levels in kelp forest systems. Kelp is an important food source for many organisms throughout the world's oceans (Dayton 1985, Duggins et al. 1989, Kaehler et al. 2006), and the large variations in isotope values of kelp tissue will likely be transferred to basal consumers. It is important to understand these patterns of temporal and spatial variability so that they can be appropriately incorporated into diet mixing models for consumers. This study provides a snap-shot look of how terrestrial and oceanic inputs combine to influence the nearshore Macrocystis community in Big Sur. These data also serve as an important baseline index of the interplay between allochthonous subsidies in the nearshore habitats along the Big Sur coast where human alterations to the terrestrial and marine landscapes are currently minimal.

Acknowledgements. We thank P. Dal Ferro, J. Krupa, K. Schoenrock, A. Pesce, and D. Andreasen for helping to collect, prepare, and/or process samples. Thanks to P. Raimondi, D. Reed, M. Carr, and K. Bruland for helpful comments on earlier versions of this manuscript. Funding was provided by the California Coastal Environmental Quality Initiative, the STEPS Institution at UCSC, the Friends of Long Marine Lab, the Myers Oceanographic Foundation, the PADI Foundation, the Mildred E. Mathias Grant Program, the Center for the Dynamics and Evolution of the Land-Sea Interface, and an NSFGRFP to M.M.F. This work was conducted under a permit from NOAA's Monterey Bay National Marine Sanctuary. This is PISCO contribution number 367 from the Partnership for Interdisciplinary Studies of the Coastal Ocean, a consortium funded by generous contributions from the Gordon and Betty Moore Foundation and the David and Lucile Packard Foundation.

\section{LITERATURE CITED}

Altabet MA, Francois R (1994) Sedimentary nitrogen isotopic ratio as a recorder for surface ocean nitrate utilization. Global Biogeochem Cycles 8:103-116

Altabet MA, Pilskaln C, Thunell R, Pride C, Sigman D, Chavez F, Francois R (1999) The nitrogen isotope biogeochemistry of sinking particles from the margin of the East- ern North Pacific. Deep-Sea Res 46:655-679

Barth JA, Menge BA, Lubchenco J, Chan F and others (2007) Delayed upwelling alters nearshore coastal ocean ecosystems in the northern California current. Proc Natl Acad Sci USA 104:3719-3724

Bernasconi SM, Barbieri A, Simona M (1997) Carbon and nitrogen isotope variations in sedimenting organic matter in Lake Lugano. Limnol Oceanogr 42:1755-1765

Bowen JL, Valiela I (2008) Using $\delta^{15} \mathrm{~N}$ to assess coupling between watersheds and estuaries in temperate and tropical regions. J Coast Res 24:804-813

> Broitman BR, Blanchette CA, Menge BA, Lubchenco J and others (2008) Spatial and temporal patterns of invertebrate recruitment along the west coast of the United States. Ecol Monogr 78:403-421

> Buschmann AH, Vásquez J, Osorio P, Reyes E, Filún L, Hernández-González MC, Vega A (2004) The effect of water movement, temperature and salinity on abundance and reproductive patterns of Macrocystis spp. (Phaeophyta) at different latitudes in Chile. Mar Biol 145: 849-862

Cifuentes LA, Sharp JH, Fogel ML (1988) Stable carbon and nitrogen isotope biogeochemistry in the Delaware Estuary. Limnol Oceanogr 33:1102-1115

Croll DA, Marinovic B, Benson S, Chavez FP, Black N, Ternullo R, Tershy BR (2005) From wind to whales: trophic links in a coastal upwelling system. Mar Ecol Prog Ser 289: $117-130$

Dayton PK (1985) Ecology of kelp communities. Annu Rev Ecol Syst 16:215-245

> Dayton PK, Tegner MJ, Edwards PB, Riser KL (1999) Temporal and spatial scales of kelp demography: the role of oceanographic climate. Ecol Monogr 69:219-250

Diffenbaugh NS, Snyder MA, Sloan LC (2004) Could $\mathrm{CO}_{2}{ }^{-}$ induced land-cover feedbacks alter near-shore upwelling regimes? Proc Natl Acad Sci USA 101:27-32

$>$ Doctor DH, Kendall C, Sebestyen SD, Shanley JB, Ote N, Boyer EW (2008) Carbon isotope fractionation of dissolved inorganic carbon (DIC) due to outgassing of carbon dioxide from a headwater stream. Hydrol Process 22: 2410-2423

> Duggins DO, Simenstad CA, Estes JA (1989) Magnification of secondary production by kelp detritus in coastal marine ecosystems. Science 245:170-173

Farquhar GD, Ehleringer JR, Hubick KT (1989) Carbon isotope discrimination and photosynthesis. Annu Rev Plant Physiol Plant Mol Biol 40:503-537

> Fogel ML, Cifuentes LA, Velinsky DJ, Sharp JH (1992) Relationship of carbon availability in estuarine phytoplankton to isotopic composition. Mar Ecol Prog Ser 82:291-300

Foster MS, Vanblaricom GR (2001) Spatial variation in kelp forest communities along the Big Sur coast of central California, USA. Cryptogam Algol 22:173-186

Fry B (2006) Stable isotope ecology. Springer, New York, NY Gaylord B, Rosman JH, Reed DC, Koseff JR and others (2007) Spatial patterns of flow and their modification within and around a giant kelp forest. Limnol Oceanogr 52: 1838-1852

Graham MH, Vasquez JA, Buschmann AH (2007) Global ecology of the giant kelp Macrocystis: from ecotypes to ecosystems. Oceanogr Mar Biol Annu Rev 45:39-88

> Handley LL, Scrimgeour CM (1997) Terrestrial plant ecology and ${ }^{15} \mathrm{~N}$ natural abundance: the present limits to interpretation for uncultivated systems with original data from a Scottish old field. Adv Ecol Res 27:133-212

Hepburn CD, Hurd CL (2005) Conditional mutualism between the giant kelp Macrocystis pyrifera and colonial epifauna. Mar Ecol Prog Ser 302:37-48 
Hepburn CD, Holborow JD, Wing SR, Frew RD, Hurd CL (2007) Exposure to waves enhances the growth rate and nitrogen status of the giant kelp Macrocystis pyrifera. Mar Ecol Prog Ser 339:99-108

Hurd CL (2000) Water motion, marine macroalgal physiology, and production. J Phycol 36:453-472

Kaehler S, Pakhomov EA, Kalin RM, Davis S (2006) Trophic importance of kelp-derived suspended particulate matter in a through-flow sub-Antarctic system. Mar Ecol Prog Ser 316:17-22

Kaldy JE, Cifuentes LA, Brock D (2005) Using stable isotope analyses to assess carbon dynamics in a shallow subtropical estuary. Estuaries 28:86-95

Kjonaas OJ, Wright RF (2007) Use of ${ }^{15} \mathrm{~N}$-labelled nitrogen deposition to quantify the source of nitrogen in runoff at a coniferous-forested catchment at Gardsjon, Sweden. Environ Pollut 147:791-799

Kudela RM, Garfield N, Bruland KW (2006) Bio-optical signatures and biogeochemistry from intense upwelling and relaxation in coastal California. Deep-Sea Res 53: 2999-3022

Lyons WB, Nezat CA, Carey AE, Hicks DM (2002) Organic carbon fluxes to the ocean from high-standing islands. Geology 30:443-446

> Manley SL (1981) Iron uptake and translocation by Macrocystis pyrifera. Plant Physiol 68:914-918

Marshall VG (2000) Impacts of forest harvesting on biological processes in northern forest soils. For Ecol Manag 133:43-60

Matsunaga K, Kawaguchi T, Suzuki Y, Nigi G (1999) The role of terrestrial humic substances on the shift of kelp community to crustose coralline algae community of the southern Hokkaido Island in the Japan Sea. J Exp Mar Biol Ecol 241:193-205

Mitchell MJ, Piatek KB, Christopher S, Mayer B, Kendall C, McHale P (2006) Solute sources in stream water during consecutive fall storms in a northern hardwood forest watershed: a combined hydrological, chemical and isotopic approach. Biogeochemistry 78:217-246

> Ortiz JD, Mix AC, Wheeler PA, Key RM (2000) Anthropogenic $\mathrm{CO}_{2}$ invasion into the northeast Pacific based on concurrent $\delta^{13} \mathrm{C}_{\mathrm{DIC}}$ and nutrient profiles from the California Current. Global Biogeochem Cycles 14:917-929

Ostrom NE, Macko SA, Deibel D, Thompson RJ (1997) Seasonal variation in the stable carbon and nitrogen isotope biogeochemistry of a coastal cold ocean environment. Geochim Cosmochim Acta 61:2929-2942

Page HM, Reed DC, Brzezinski MA, Melack JM, Dugan JE (2008) Assessing the importance of land and marine sources of organic matter to kelp forest food webs. Mar Ecol Prog Ser 360:47-62

Parsons TR, Maita Y, Lalli CM (1984) A manual of chemical and biological methods for seawater analysis. Pergamon, New York, NY

Quinn GP, Keough MJ (2002) Experimental design and data analysis for biologists. Cambridge University Press, Cambridge

Editorial responsibility: Laura Airoldi, Ravenna, Italy
Rau GH, Riebesell U, Wolf-Gladrow D (1997) $\mathrm{CO}_{2 a q}$-dependent photosynthetic ${ }^{13} \mathrm{C}$ fractionation in the ocean: a model versus measurements. Global Biogeochem Cycles 11: 267-278

Rau GH, Low C, Pennington JT, Buck KR, Chavez FP (1998) Suspended particulate nitrogen $\delta^{15} \mathrm{~N}$ versus nitrate utilization: observations in Monterey Bay, CA. Deep-Sea Res 45: 1603-1616

Raven JA (1970) Exogenous inorganic carbon sources in plant photosynthesis. Biol Rev Camb Philos Soc 45:167-220

> Raven JA, Johnston AM, Kubler JE, Korb R and others (2002) Mechanistic interpretation of carbon isotope discrimination by marine macroalgae and seagrasses. Funct Plant Biol 29:355-378

Raven JA, Cockell CS, La Rocha CL (2008) The evolution of inorganic carbon concentrating mechanisms in photosynthesis. Philos Trans R Soc Lond B Biol Sci 363: 2641-2650

Reed DC, Rassweiler A, Arkema KK (2008) Biomass rather than growth rate determines variation in net primary production by giant kelp. Ecology 89:2493-2505

Schindler DE, Scheuerell MD (2002) Habitat coupling in lake ecosystems. Oikos 98:177-189

Spoelstra J, Schiff SL, Elgood RJ, Semkin RG, Jeffries DS (2001) Tracing the sources of exported nitrate in the Turkey Lakes watershed using ${ }^{15} \mathrm{~N} /{ }^{14} \mathrm{~N}$ and ${ }^{18} \mathrm{O} /{ }^{16} \mathrm{O}$ isotopic ratios. Ecosystems 4:536-544

Waldron S, Scott EM, Soulsby C (2007) Stable isotope analysis reveals lower-order river dissolved inorganic carbon pools are highly dynamic. Environ Sci Technol 41: 6156-6162

> Wankel SD, Kendall C, Pennington JT, Chavez FP, Paytan A (2007) Nitrification in the euphotic zone as evidenced by nitrate dual isotopic composition: observations from Monterey Bay, California. Global Biogeochem Cycles 21: GB2009

Warrick JA, Fong DA (2004) Dispersal scaling from the world's rivers. Geophys Res Lett 31: L04301

> Warrick JA, Washburn L, Brzezinski MA, Siegel DA (2005) Nutrient contributions to the Santa Barbara Channel, California, from the ephemeral Santa Clara River. Estuar Coast Shelf Sci 62:559-574

Wheeler WN (1977) Interrelationship between light, water velocity, and macronutrients in productivity of giant kelp, Macrocystis. J Phycol 13:72

- Woodson CB, Eerkes-Medrano DI, Flores-Morales A, Foley MM and others (2007) Local diurnal upwelling driven by sea breezes in northern Monterey Bay. Cont Shelf Res 27: 2289-2302

Zehr JP, Ward BB (2002) Nitrogen cycling in the ocean: new perspectives on processes and paradigms. Appl Environ Microbiol 68:1015-1024

Zimmerman RC, Kremer JN (1986) In situ growth and chemical composition of the giant kelp, Macrocystis pyrifera: response to temporal changes in ambient nutrient availability. Mar Ecol Prog Ser 27:277-285

Submitted: November 26, 2009; Accepted: March 26, 2010 Proofs received from author(s): June 2, 2010 